\title{
The effect of municipality size and local office on the electoral success of Belgian/Flemish election candidates: a multilevel analysis
}

\author{
Accepted for publication in Government and Opposition
}

GERT-JAN PUT AND BART MADDENS

\section{INTRODUCTION}

This article examines the effect of local characteristics of candidates on their results in legislative elections. Previous research (Tavits 2010; Smith et al. 2012) has shown that locallevel political experience is a trait which has a significant effect on the number of preferential votes. This contribution adds to this research by focusing on the combined effect of local political office and the size of the candidate's place of residence. We argue that the local office effect is dependent on the size of the municipality : the larger the municipality, the stronger the effect of local office on the number of preferential votes at the aggregate level. By analysing the impact of these two local background variables, we attempt to gain a better understanding of which candidates can build a personal reputation on the basis of their local ties, and to what extent this personal reputation secures their (re)election.

Our research builds on the growing literature about local ties of a candidate as a crucial personal vote-earning attribute (PVEA). Earlier research has shown that having local ties increases the chances of a politician to be selected as a candidate (Gallagher 1988). Other studies have focused on the effects of these attributes on legislative behaviour (Crisp et al. 2004; Tavits 2009; Marangoni and Tronconi 2011). They have shown that candidates and legislators with local PVEA attributes are more likely to display constituency-oriented behaviour. But, most crucially, there is also convincing evidence that candidates can earn votes by emphasising their local roots and their local political experience during the campaign. Candidates with local PVEA appear to obtain significantly more votes than candidates without such attributes. Moreover, holding local office is found to be crucial attribute in that respect (Blais et al. 2003; Tavits 2010; Smith et al. 2012).

The hypothesis that this impact of local office on the electoral result depends on the size of the municipality will be tested with data about five consecutive federal and regional elections in Belgium. These elections are useful cases as they are held under a semi-open proportional or flexible list system (Marsh 1985; Shugart 2005). Recently, electoral reforms adapted both district magnitude and the relative weight of the party list vote, making the Belgian system more candidate-centred. These two developments led to the increased importance of the personal versus party reputation: upgrading the impact of preferential votes created a stronger incentive for candidates to cultivate personal votes. In turn, this might lead Belgian parties to nominate increasingly more candidates with personal vote-earning attributes.

In what follows, we first outline the main theoretical argument on the basis of the existing literature on the personal vote, and develop a number of hypotheses. Subsequently, we discuss the recent reforms in the Belgian electoral system and their consequences. The next section elaborates on the dataset of personal characteristics of Belgian/Flemish election candidates, the variable operationalization and the used method. In the fifth section, we discuss the results of the multilevel analyses. Finally, the conclusion puts the implications of this study in theoretical perspective. 
As originally argued by Carey and Shugart (1995), the importance of the personal vote heavily depends on the electoral system type and how votes are cast. More specifically, ballot and vote type, vote pooling and district magnitude determine whether the electoral system is more party- or candidate-centered. In party-centered electoral systems, politicians are inclined to display the party label during campaign time and cultivate party votes. In candidatecentered systems, however, it is more important for candidates to cultivate personal votes and to build personal reputations. Some authors claim that in the latter category of electoral systems, the political party is being replaced by the individual candidate as the primary criterion of choice (van Holsteyn and Andeweg 2010). Candidates will increasingly display personal vote-seeking behavior to cultivate personal votes. This implies that parties will have more difficulties in maintaining internal cohesion, and that voters are increasingly more influenced by candidate-based attributes than party-based attributes (Thijssen 2013).

One strand of research on the personal vote has focused on how candidates or legislators cultivate personal votes, and build personal reputations that increase their chances of reelection. Legislators could, for example, engage in constituency service or pork barrel politics to please their constituents (Mayhew 1974; Lancaster and Patterson 1990). In addition, some authors claim that specific personal characteristics of legislators allow them to earn personal votes, reducing the need to cultivate personal votes by means of constituency service (Shugart et al. 2005; Martin 2010). The literature provides several examples of these so-called personal vote-earning attributes (PVEA). Voters use these attributes as an information shortcut in their voting decisions, resulting in significantly more personal votes for this type of candidates.

Firstly, the gender, class, race and religion of candidates possibly attracts personal votes from their respective subgroups in society. Ethnic voters might, for example, feel that their concerns will be addressed by the party that includes candidates with the same ethnic background on their list. As a result, the inclusion of candidates from all social groups is an easy way for party selectorates to broaden the appeal of their list to a larger group of voters. However, in some electoral systems party selectorates might feel that candidate diversity on lists is undesirable (Valdini 2012). Especially in single member district systems, selectorates fear that candidates with other ethnic backgrounds or with a very specific religious profile will harm their electoral fortune.

Secondly, another category of candidate characteristics are universally interesting and appealing, regardless of the electoral system, such as previous electoral and political experience, and local roots. The incumbency advantage, for example, has been extensively documented in the literature (Gelman and King 1990; Cox and Katz 1996; Carson et al. 2007). Incumbents have already proven their electoral appeal in the previous election. Their office also provided them with ample media attention and visibility, as well as an organizational capacity which can be relied on during the campaign. But especially the fact that incumbent candidates have some previous experience in what they are running for, might shape voters' ballot decisions and attract additional personal votes. In addition, the possession of local roots in the electoral district is also a universally appealing candidate trait. Candidates with these characteristics, often referred to as local PVEA, can make a more convincing claim that they are well aware of local constituency needs. As a consequence, one expects candidates with local PVEA to be electorally more successful than competitors without local roots. Tavits (2010) provides the most thorough and systematic empirical test of this assumption on the basis of data on national election candidates from Estonia.

In that study, local political experience and being a district native are used as indicators of local ties. The first measure appears to be an adequate predictor of individual 
candidate performance. There are several reasons why local office-holders would have significantly more electoral appeal. First, holding local office leads to a level of name recognition among the electorate. Second, local office-holders might have done some casework for (influential) members of the community, thereby proving their commitment to the local needs and strengthening their local networks. And third, as previously mentioned, local councillors, aldermen and mayors are generally more convincing in their claims to know what the local community wants.

The political experience at the local level has thus been recognized as a reliable indicator of local ties. Holding political office in the municipality has already been shown to constitute a useful measure of local ties, and appears to be an electorally rewarding personal attribute for candidates. Hence the first hypothesis:

\section{Hypothesis 1: Candidates who hold a political office at the local level are likely to be more successful in terms of preferential votes than candidates who do not.}

According to previous research, holding local office is an important asset in parliamentary elections. Moreover, this effect increases with the prominence of the office. It are particularly the executive functions in the municipality which provide an electoral bonus for candidates in national elections.

The second measure used in the analysis of Tavits (2010), however, lacks explanatory power. Being a district native failed to have any substantial effect on the individual candidate results. A second relevant study also uses local birth as one of three components in their PVEA index, and comes to a similar conclusion when testing the effect of local PVEA on candidate success: locally born candidates are not more likely to get elected than candidates lacking such ties (Smith et al. 2012).

There are several reasons why district nativity or local birthplace might not be a good predictor of candidate success. Perhaps, being born in a particular district or municipality is not so important to voters at all. It might only be a weak proof of local ties, and is far less salient than being a local politician. As Tavits (2010: 226) correctly states: 'Birthplace may not convey any meaningful information about a candidate who has lived most of their adult life elsewhere.' Indeed, even the parachutists - i.e. candidates coming from outside the district, but nominated and elected in their new constituency (Pedersen et al. 2007) - might be able to develop local ties in their new district, making their local birthplace totally irrelevant for their new voters. Moreover, the birthplace of candidates is not always very well-known to the electorate.

In the present research, we focus on municipality size instead of birthplace. We hypothesize that the municipality size of candidates is an important variable which moderates the effect of local roots on the individual result of election candidates at the aggregate level. ${ }^{1}$ Candidates will be able to capitalize on their knowledge of the local needs and sensibilities, and on the local political network they have developed in the municipality. This will increase the electoral result within the municipality. But it is only when the municipality is sufficiently large relative to the constituency as a whole that this effect will also translate into a significantly better electoral result at the constituency level. In other words, candidates living in relatively large municipalities will be advantaged compared to candidates from smaller municipalities. This leads to the following hypothesis:

Hypothesis 2: The larger the population share of the candidate's municipality in the electoral district, the higher the relative number of preferential votes for that candidate. 
Additionally, we argue that municipality size will interact positively with the political office variable: the larger the municipality, the larger the effect on the number of preferential votes at the municipality level. This is so for two reasons. First, holding local political office in a large city leads to a comparatively larger local network than in a small municipality, both in terms of grassroots party volunteers and constituents. Activating this network in parliamentary elections would then result in a higher level of electoral success compared to local office-holders in small municipalities. Second, the electoral appeal of holding a local office is larger for election candidates in large municipalities, simply because they appeal to a larger group of constituents than their colleagues in small municipalities. There are substantially more inhabitants who feel that they share their local background with the candidate, and perceive them as truly committed to the needs of the local community.

We acknowledge that, on the basis of the political geography literature, one might arrive at an opposite hypothesis. According to this literature, the social distance between constituents and local representatives is substantially larger in cities than in the less densely populated areas: smaller municipalities provide the opportunity for greater levels of contact, peer networks and knowledge of the representatives (Lewis-Beck and Rice 1983). Also, local attachment in urbanised areas is often comparatively weaker (Sampson 1988). According to this reasoning, the effect of local office will decrease if the candidate lives in a larger municipality. However, we believe that the aforementioned positive effect of living in a larger municipality will outweigh these possible negative effects. This implies that local officeholders in large cities have a structural advantage, and that the size of their place of residence functions as a personal vote multiplier, reinforcing the positive effect of holding local political office.

In other words, however popular the mayor of a village may be, if the population size is small, the electoral effect in terms of individual preferential votes at the aggregate constituency level will be relatively smaller than the effect for local office holders in large municipalities. This leads to a third hypothesis:

\section{Hypothesis 3: Candidates who are local political office holders in large municipalities are likely to be more successful than similar candidates in small municipalities.}

\section{THE ELECTORAL SYSTEM OF BELGIUM}

The Belgian electoral system is often characterized as a semi-open or flexible list PR system (Marsh 1985; Shugart 2005). In such a system, voters are able to endorse a party list as a whole or to cast one or more preferential votes for specific candidates. In theory, both the list order and the number of preferential votes play an important role in the intraparty seat allocation. In practice, however, the threshold of preferential votes to overcome the list order is reached very infrequently, which led scholars to characterize flexible list systems as closedlist systems in disguise (De Winter 2005; Crisp et al. 2013).

In recent years, the Belgian system has experienced a number of important electoral reforms. In the remainder of this section, we shortly discuss these reforms and their impact on the personal vote-seeking behaviour of Belgian party candidates.

First, the relative weight of the list vote in determining which candidates are elected was changed. The impact of the preferential votes on the actual allocation of seats used to be very marginal. This was so because the votes at the head of the list, the so called list votes, were first transferred to the candidates in the order of their position on the list. As a consequence, the candidates at the top of the list were almost guaranteed of their seat and the intra-list competition between candidates was to a certain extent neutralized. Thus, the system 
effectively functioned as a closed list system, the allocation of seats to candidates being determined in large part by pre-electoral intra-party bargaining. In 2000, the electoral law was changed in the sense that the transferral of list votes was reduced by half. This implies that the number of candidates that can be elected on the basis of list votes is reduced and intra-list competition between candidates has become more important (Wauters and Weekers 2008). This resulted in a larger share of candidates leap-frogging past higher-ranked co-partisans (Wauters et al. 2004).

Second, the mean district magnitude in Belgium has increased significantly over the last two decades. The two district reforms of 1993 and 2002 also led to more intra-list competition between candidates, and thus encourages candidates to maximise their personal score. Especially the second district reform was relatively controversial and has been debated extensively in the Belgian political arena. Opponents feared that the enlargement of electoral districts would lead to an increased nationalization of election campaigns and scores, rendering the local ties of candidates unimportant (Pilet 2007). In addition, it was argued that it would become increasingly difficult for rural candidates to get campaign visibility, or even to get nominated on candidate lists (Maddens et al. 2014).

Both the increase in district magnitude and the decreased relative weight of list votes resulted in a more transparent system, in which it is easier to understand for the voter how seats are allocated to parties and candidates. At the same time, these reforms strengthened the tendency towards more candidate-centred campaigns, with a strong focus on the competition between individual candidates, both between and within lists (De Winter 2005). This focus on candidates is reflected in the voting behaviour. The percentage of voters casting a preferential vote increased substantially during the previous decade. André et al. (2012) calculated that more than $60 \%$ of Belgian voters cast a preferential vote in the federal elections of 2003, with a slight decline at the subsequent federal elections. Moreover, they find comparable percentages for the 2009 Flemish and Walloon elections.

The fact that local ties are important in the Belgian system is also reflected by the relatively high share of candidates with local office selected by the Flemish parties for the federal and regional elections since 2003. Taken together, 50.4\% of all the candidates are incumbent local office holders. Most of these candidates (65.9\%) are a member of the local council. Furthermore, $34.1 \%$ are a member of the executive, of which $23 \%$ are alderman (i.e. a member of the executive body) and $11.1 \%$ are mayor (i.e. the head of the executive body). Previous research has shown that these local office holders, particularly the mayors, are also more likely to be selected as a realistic candidate, i.e. a candidate who has a realistic chance of obtaining a seat (Put and Maddens 2013).

\section{DATA AND METHOD}

The data cover the elections for the federal House and the Flemish Parliament during the period 2003-2010. The analysis is limited to the Flemish parties that already had at least one seat in one of the Belgian Parliaments during the legislative term preceding the election under investigation. ${ }^{2}$ This results in a vast dataset of 5540 election candidates ${ }^{3}$ on 179 different party lists.

There are substantial reasons why we do not expect to see differences between the elections of the federal House of Representatives and the Flemish Parliament. In the Flemish part of the country, the scale on which the elections take place on both levels since 2003 is identical, i.e. provincial constituencies. Moreover, Belgium has the peculiar feature of having two completely separate regional party systems in Flanders and Wallonia, which implies that the parties competing with each other on the federal and regional level are exactly the same 
(Verleden 2009). As already mentioned, the amount of local office holders among the candidates for both assemblies is also comparable. In addition, the fact that there is a relatively high degree of level-hopping in the Belgian political arena, proves that politicians themselves rate the federal and regional level as relatively equal (Vanlangenakker et al. 2013).

Alternatively, a counterargument might be that local policy issues are more salient in regional elections, as the regions have the legislative powers with regard to local matters. More specifically, candidates for the regional assembly might stress local issues more strongly than their counterparts at the federal level, resulting in a stronger impact of local PVEA in regional elections. We add a dummy variable to the model indicating whether the candidate stands in the federal and the regional election, and test whether there is an interaction effect with local office and municipality size.

We will apply multilevel analysis when testing the aforementioned hypotheses. First, these election data have a nested structure. In the Belgian flexible list system, each individual election candidate is placed on a party list among other candidates. These lists all have their own characteristics, and constitute an additional explanatory level for the individual number of preferential votes. Second, we expect some of the aggregate characteristics of these party lists to contribute to the electoral success of individual candidates. More specifically, the percentage of votes for the list in the constituency will automatically have a positive effect on the number of preferential votes of every candidate on that particular list. As a result, it is appropriate to apply multilevel analysis. Classic regression models would not take the possible correlations within party lists into account, resulting in inaccurately estimated parameters. Multilevel analysis allows for taking the intra class-correlation and the variance between party lists into account.

The dependent variable is the percentage of preferential votes for the candidate, calculated on the basis of the total number of valid votes in the constituency. ${ }^{4}$ As this variable is highly skewed and values are all-positive, it is advisable to apply a logarithmic transformation. ${ }^{5}$ This transformation overemphasizes differences between candidates in the low range of preferential votes, and underemphasizes differences among candidates in the high range, which we see as an additional argument rather than a problem: we wish to explain significant differences in numbers of preferential votes among a large group of candidates, by testing the effect of a number of political and socio-economic candidate traits. For candidates in the high range, there are often idiosyncratic factors at work, which might explain their unusual high numbers of preferential votes, but are less interesting in explaining the variation in preferential votes for a large number of election candidates. ${ }^{6}$

Of course, transforming the dependent variable often makes it more difficult to interpret the meaning of the Beta coefficients of regression models. In addition, our dataset contains a number of variables that measure on completely different scales. To make the estimated Beta coefficients of the independent variables at least comparable in terms of scale and size of the effects, we standardized the continuous variables included in the analysis. ${ }^{7}$ Categorical variables are not standardized, as there is no meaningful interpretation for their standardized coefficients.

In sum, we disentangle three groups of independent variables. Firstly, it is important to control for some mechanical effects. At the individual level, the electoral result is in large part determined by the position on the list. It has been shown that candidates in critical positions on the ballot form automatically draw more votes, even when other factors such as incumbency are controlled for (Geys and Heyndels 2003). There are several explanations for this phenomenon, such as the fact that voters are inclined to start evaluating candidates from the top of the ballot, and are decreasingly capable, willing and interested to consider options as they move down the ballot (Taebel 1975; Lutz 2010). Furthermore, undecided voters tend to give preferential votes to candidates who appear at the top of the ballot list (Miller and 
Krosnick 1998). High positions on the list also imply higher campaign spending caps, which gives the candidates more leeway to wage an extensive campaign. The main critical positions are those at the top and the bottom of the list. We include the first five positions, the before last and the last position on the list as dummies in our analysis, with the other positions as reference category.

Secondly, at the list level, the party strength (i.e. the number of votes for the list as a percentage of the total number of valid votes in the constituency) is a crucial variable that has an automatic effect on the electoral result at the individual level: the more votes the list obtains in the constituency, the larger the potential number of preferential votes available for the candidates on the list. The second list level variable is the election type, measured as a binary variable indicating whether the candidate list is for the federal or regional elections. The interaction of this variable with local office and municipality size will indicate whether there are any substantial differences between the effects of local PVEA in regional and federal elections.

The third group of independent variables are the candidate characteristics. We collected information about the age, occupational status and sex of candidates. Six categories of occupational status are distinguished : (1) candidates without a job, (2) self-employed candidates, (3) workers, (4) employees, (5) civil servants and (6) party professionals or members of the personal staff of a minister. In addition to a binary variable expressing the sex of the candidate, we also add a dummy variable to indicate the first female candidate on the list. Previous research has demonstrated that 'gender voters' are highly selective and tend to vote for those women candidates who occupy the best ballot position (Thijssen 2013). ${ }^{8}$

Candidates can also increase their votes by waging an extensive electoral campaign. A number of authors have examined the effect of several campaigning variables on the amount of preferential votes. First, media exposure and electoral success are often considered to go hand in hand (Van Aelst et al. 2008). Previous research has indeed confirmed that media attention contributes to the individual success of candidates (Maddens et al. 2006). Second, there has been a recent surge in attention for the political impact of social media campaigns (Spierings and Jacobs 2013). Third, the amplitude of a candidate's election campaign can also be measured by his/her level of campaign spending. We collected data on the personal investment of each of the 5540 candidates in our dataset, and add it as a control variable to the multivariate analysis. It can be assumed that the relationship between the expenses and the electoral outcome is non-linear, in the sense that the marginal returns of spending will gradually decrease with the amount spent. To allow for this possibility the normal practice in campaign expense research is to also include the squared expenses in the regression model. The squared spending term is expected to have a negative coefficient (e.g. Palda 1994; Samuels 2001).

In addition, we also registered whether the candidates have previously been minister or MP at any given point in their career. Self-evidently, former ministers and MPs are highly attractive candidates and their level of political experience will result in a substantially higher number of preferential votes. By controlling for the former offices of electoral candidates, we exclude the possibility that the apparent positive effect of their local office is actually caused by their previous experience at the regional or national level. To the extent that local office holders in large municipalities used to be prominent figures at a higher political level, their electoral success might not be due to their local PVEA, but rather to their national reputation built up during an earlier stage of the political career. These former office-variables are expected to have high explanatory power in our multilevel models. A former MP/minister is defined as a candidate who has already been MP or minister before the election, at either the regional, federal or European level. To avoid multicollinearity between these two binary 
independent variables, we include them as mutually exclusive variables: a candidate with previous experience as both a minister and MP will only be registered as former minister.

More important for this study, we take into account local-level incumbency, more in particular currently holding an office as either mayor, alderman or member of the local council. As explained above, we will also investigate whether the effect of holding local political office interacts with municipality size, i.e. the population size of the candidate's place of residence.

\section{MULTILEVEL ANALYSIS}

We test two multilevel regression models to address the three hypotheses formulated earlier in this article. The first model includes the mechanical effects that function as control variables, and the candidate characteristics which include local political office and relative municipality size. The results of this first analysis indicate whether Hypothesis 1 and Hypothesis 2 hold true on the basis of our data on the Belgian case. The second model adds the interaction effects between these two local PVEA, which allows us to test Hypothesis 3.

< Table 1 about here >

Table 1 reports the results of these two multilevel models. The size and sign of these beta coefficients indicate the change in the dependent variable (standardized logged preferential votes of candidates). With regard to Model 1, it can be observed that both the candidate-level and list-level mechanical effects have the expected strong impact on the relative number of preferential votes for individual candidates. Concerning list position, the size of the coefficients decreases neatly which confirms that the visible positions at the top of the list are electorally far more attractive. In addition, the results show that candidates on the list pusher position enjoy an electoral advantage $(+0.29)$ compared to the less visible positions in the middle of the list. In general, successor candidates ${ }^{9}$ obtain significantly less preferential votes compared to the reference category (-0.13). At the list level, the electoral strength obviously has a significant effect on the percentage of preferential votes for individual candidates $(+0.37)$.

No less than four individual-level social background variables included in the model have a significant effect. Controlling for list position and political office variables, there seems to be a small difference in the number of preferential votes for men and women. The results of Model 1 point in the direction of a disadvantage for male candidates compared to their female counterparts. It is often the case that women candidates are disadvantaged by some other factors. For instance, previous research has shown that women generally occupy a lower position on the list, are less often incumbent or spend less than men. Once such disadvantages are controlled for, the negative effect for women disappears, or is sometimes even reversed (Wauters et al. 2010). Being the first female candidate on the list does not yield an electoral bonus according to our data. Age, operationalized as a continuous variable, has a significant but negligibly small effect on the number of preferential votes, in the sense that older candidates will on average receive less votes. ${ }^{10}$ Profession also has an effect in the sense that candidates with a job as civil servant have a small electoral disadvantage (-0.06) compared to the reference category of employees. Finally, the individual campaign spending variable proves that personal investments in campaigning significantly increases a candidate's 
preferential votes $(+0.11)$. The squared expenses-variable has the expected negative sign, but it does not have a significant effect.

Model 1 also includes the size of the candidate's municipality, measured as the population share of the municipality in the constituency. The results indicate that this attribute in itself increases the candidate's preferential votes, albeit rather modestly $(+0.02)$. Model 1 suggests that the electoral success of individual party candidates is positively influenced by the relative size of his municipality in the constituency, which is in line with the second hypothesis.

The first hypothesis, however, is but partially confirmed. Only the highest local office significantly increases the relative number of preferential votes for individual candidates. This large effect of being mayor $(+0.21)$ contrasts with the other two types of local office, alderman and local councillor. Apparently, these local political functions do not generate any additional personal votes. It appears that the mayors capitalize on their prior local experience, and eclipse the other types of local office. Nevertheless, these effects of local ties are dwarfed by the effect of being a former minister $(+1.15)$. But the electoral advantage of being a former MP (+0.29) is more or less comparable to the effect of being a mayor. The final rows in the table report the level 1 (between candidates) and level 2 (between lists) variance. At both levels, there is still some significant variance to be explained, especially at the candidate level. The IGLS deviance is a measure that allows us to compare the goodness of fit of the multilevel model. The lower the score, the better the fit.

In Model 2, we add the interaction terms for each of the local offices and relative municipality size. If Hypothesis 3 holds true, all three interactions should have a significant and positive effect on the dependent variable. This appears to be the case, but the level of significance varies strongly over the type of local office. For mayors, there is a large interaction effect $(+0.56)$ which is significant at the level of $\alpha=0.001$. Concerning aldermen and local councilors, this effect is considerably smaller, and significant at the level of $\alpha=$ 0.05. Adding the interaction terms has strengthened the size of the main effect of being a mayor. At the same time, this made the significant main effect of municipality size, which was present in Model 1, disappear. Additionally, we added the interaction terms for the local offices and election type. Only the interaction term with mayors is significant, but it has a positive sign. Earlier, we argued that local PVEA might have a stronger effect in regional elections, as the regions are competent for local matters. The data do not support this argument: on the contrary, mayors seem to get an even stronger bonus at the federal level. Finally, the interaction term of municipality size and election type is also not significant.

In sum, these results suggest, that the local office of mayor in itself generates a large electoral advantage compared to election candidates without any local office, or other types of local officeholders. In addition, the electoral asset of being a mayor increases significantly with municipality size. The larger the municipality of the mayor, the stronger his/her advantage in terms of preferential votes. Second, the local office of alderman and local councillor is not rewarding in itself. In other words, Hypothesis 1 only holds for the office of mayor. Still, this does not mean that holding a less important office is not electorally rewarding. But this effect is limited to the office holders from the larger municipalities, as indicated by the significant interaction effect. For the office of mayor, both the main effect and the interaction with municipality size are significant. Hence, Hypothesis 3 is confirmed. Once the interactions between office and municipality size are included in the model, the main effect of municipality size disappears. Hence, Hypothesis 2 has to be rejected. Municipality size only affects the number of preferential votes of local officeholders through the interaction terms with the type of local office. The argument that large city candidates appeal to a larger share of voters in the district on the basis of a shared local background, does 
not hold true according to our data. This logic only works for local officeholders, whose electoral advantage appears strongly dependent on the size of their municipality.

\section{CONCLUSION}

The present study has examined the impact of local ties on electoral success in the case of the Belgian House elections and Flemish regional elections. We argued that local birthplace, which is frequently used in existing research, is not a suitable indicator of local ties. Instead, we operationalized the local ties of a candidate on the basis of the political functions he/she occupies in the municipality, moderated by the size of their respective municipalities.

Our multilevel analyses lead to three findings. First, the idea that holding political office at the local level is an important PVEA for party candidates, only counts for mayors in our analysis. To our knowledge, previous studies did not make the distinction between various types of local office. However, our research shows that the effect depends on the nature of the local office, and that it is thus crucial to distinguish between, for instance, mayors and local councillors. Second, while the relative size of a candidate's place of residence in the electoral district originally also determined the number of preferential votes, this effect disappeared when we added the interaction terms with local offices. The advantage of living in a large municipality is only substantial for election candidates when they hold a local office in their place of residence. If this is the case, these election candidates seem to appeal to a larger group of voters in the district. This brings us to the third and final finding: the effects of holding political office at the local level and municipality size interact. The electoral advantage of being a mayor, alderman or local councillor increases with the relative size of the municipality in the district.

While Belgium is of course a case with notoriously complex territorial and electoral dynamics, we believe that the results of these analyses can, to a certain extent, be generalized to other flexible list systems, and even other types of list PR systems with the possibility of casting preferential votes. The result that local political experience leads to significantly more preferential votes has previously been confirmed in a latent list system such as Estonia, and the MMP system of Japan. As the data on the Belgian flexible list system points in the same direction with regard to mayors, we might conclude that local political experience is a crucial candidate trait to attract personal votes in any system where voters are able to cast preferential votes. And even if it is the case in most flexible list systems that the number of votes cast for individual candidates almost never attains the threshold required to obtain a seat, candidates do seem to earn increasingly more individual-level preferential votes, because parties reward vote-earning candidates with better list positions in the future (Crisp et al. 2013). Earning personal votes is important for one's political career, irrespective of the extent to which the odds of obtaining a seat is dependent on the number of preferential votes.

The interaction with municipality size indicates that the group of voters which can be persuaded by having prior local political experience, is to a certain extent geographically bounded. On the basis of these results, we cannot say whether these boundaries coincide with the municipality boundaries. A more detailed analysis, including the individual candidate results per municipality or even neighbourhood within the constituency boundaries, could provide us with more insight into the geographical boundedness of local office-holders' electoral appeal. Unfortunately, these data are not available for Belgian elections.

Finally, It would be interesting to investigate whether the established effects of local ties in previous studies are also dependent of the size of candidates' localities. With regard to local political experience, this future research will also have to take into account that, according to our findings, it is crucial to distinguish between the various types of political office at the local level. 


\section{REFERENCES}

André, A., Wauters, B. and Pilet, J. (2012), 'It's not Only About Lists: Explaining Preference Voting in Belgium', Journal of Elections, Public Opinion \& Parties, 22(3): 293-313.

Blais, A., Gidengil, E., Dobrzynska, A., Nevitte, N. and Nadeau, R. (2003), 'Does the Local Candidate Matter? Candidate Effects in the Canadian Election of 2000', Canadian Journal of Political Science, 36(3): 657-64.

Carey, J.M., and Shugart, M.S. (1995), 'Incentives to Cultivate a Personal Vote: A rank ordering of electoral formulas', Electoral studies, 14(4): 417-39.

Carson, J.L., Engstrom, E.J. and Roberts, J.M. (2007), 'Candidate Quality, the Personal Vote, and the Incumbency Advantage in Congress', American Political Science Review, 101(2): 289-301.

Cox, G.W. and Katz, J.N. (1996), 'Why Did the Incumbency Advantage in US House Elections Grow?', American Journal of Political Science, 40(2): 478-97.

Crisp, B.F., Escobar-Lemmon, M.C., Jones, B.S., Jones, M.P. and Taylor-Robinson, M.M. (2004), 'Vote-Seeking Incentives and Legislative Representation in Six Presidential Democracies', Journal of Politics, 66(3): 823-46.

Crisp, B.F., Olivella, S., Malecki, M. and Sher, M. (2013), 'Vote-Earning Strategies in Flexible List Systems: Seats at the Price of Unity', Electoral Studies, 32(4): 658-69.

De Winter, L. (1997), 'Intra - and Extra - Parliamentary Role Attitudes and Behavior of Belgian MPs', Journal of Legislative Studies, 3(1): 128-54.

De Winter, L. (2005), 'Belgium: Empowering Voters or Party Elites?', M. Gallagher and P. Mitchell (eds.), The Politics of Electoral Systems (Oxford: Oxford University Press): 417-32.

Gallagher, M. (1988), 'Conclusion', in M. Gallagher and M. Marsh (eds.), Candidate Selection in Comparative Perspective: The secret Garden of Politics (London: Sage): 236-83.

Gelman, A. and King, G. (1990), 'Estimating Incumbency Advantage Without Bias', American Journal of Political Science, 34(4): 1142-64.

Geys, B. and Heyndels, B. (2003), 'Influence of Cognitive Sophistication on Ballot Layout Effects', Acta Politica, 38(4): 295-311.

Lancaster, T.D. and Patterson, W.D. (1990), 'Comparative Pork Barrel Politics: Perceptions from the West German Bundestag', Comparative Political Studies, 22(4): 458-77.

Lewis-Beck, M.S. and Rice, T.W. (1983), 'Localism in Presidential Elections: the Home State Advantage', American Journal of Political Science, 27(3): 548-56.

Lutz, G. (2010), 'First Come, First Served: the Effect of Ballot Position on Electoral Success in Open Ballot PR Elections', Representation, 46(2): 167-81. 
Maddens, B., Wauters, B., Noppe, J. and Fiers, S. (2006), 'Effects of Campaign Spending in an Open List PR System: The 2003 Legislative Elections in Flanders/Belgium', West European Politics, 29(1): 161-8.

Maddens, B., Put., G.J. and Smulders, J. (2014), Het DNA van de kandidaten: Een Doorlichting van de Kandidaten voor de Kamerverkiezingen van 1987 tot 2010. (Leuven: Acco).

Marangoni, F. and Tronconi, F. (2011), 'When Territory Matters: Parliamentary Profiles and Legislative Behaviour in Italy (1987-2008)', The Journal of Legislative Studies, 17(4): 41534.

Marsh, M. (1985), 'The Voters Decide? Preferential Voting in European List Systems', European Journal of Political Research, 13(4): 365-78.

Martin, S. (2010), 'Electoral Rewards for Personal Vote Cultivation under PR-STV', West European Politics, 33(2): 369-80.

Mayhew, D. (1974), Congress: The Electoral Connection. (New Haven: Yale University Press).

Miller, J.M. and Krosnick, J.A. (1998), 'The Impact of Candidate Name Order on Election Outcomes', Public Opinion Quarterly, 62(3): 291-330.

Palda, F. (1994), 'Desirability and Effects of Campaign Spending Limits', Crime, Law and Social Change, 21(4): 295-317.

Pedersen, M.N., Kjaer, U. and Eliassen, K.A. (2007), 'The Geographical Dimension of Parliamentary Recruitment-Among Native Sons and Parachutists', in M. Cotta and H. Best (eds.), Democratic Representation in Europe: Diversity, Change and Convergence (Oxford: Oxford University Press): 160-90.

Pilet, J.B. (2007), Changer Pour Gagner? Les Réformes des Lois Electorales en Belgique (Bruxelles: ULB).

Put, G.J. and Maddens, B. (2013), 'The Selection of Candidates for Eligible Positions on PR Lists: The Belgian/Flemish Federal Elections 1999-2010', Journal of Elections, Public Opinion \& Parties, 23(1): 49-65.

Sampson, R.J. (1988), 'Local Friendship Ties and Community Attachment in Mass Society: A Multilevel Systemic Model', American Sociological Review, 53(5): 766-79.

Samuels, D. (2001), 'Incumbents and Challengers on a Level Playing Field: Assessing the Impact of Campaign Finance in Brazil', Journal of Politics, 63(2): 569-84.

Shugart, M.S. (2005), 'Comparative Electoral Systems Research: The Maturation of a Field and New Challenges Ahead' in M. Gallagher and P. Mitchell (eds.), The Politics of Electoral Systems (Oxford: Oxford University Press): 25-57. 
Shugart, M.S., Valdini, M.E. and Suominen, K. (2005), 'Looking for Locals: Voter Information Demands and Personal Vote-Earning Attributes of Legislators under Proportional Representation', American Journal of Political Science, 49(2): 437-49.

Smith, D.M., Pekkanen, R. and Krauss, E. (2012), 'Looking for Locals, or Looking for Loyals? Party Nomination Strategies and Voter Preferences Following Electoral Reform', Paper presented at the Inaugural Meeting of the ECPR Standing Group on Parliaments, Dublin, 2012.

Spierings, N. and Jacobs, K. (2013), 'Getting Personal? The Impact of Social Media on Preferential Voting', Political Behavior, available online: [http://link.springer.com/article/10.1007/s11109-013-9228-2].

Taebel, D.A. (1975), 'The Effect of Ballot Position on Electoral Success', American Journal of Political Science, 19(3): 519-26.

Tavits, M. (2009), 'The Making of Mavericks: Local Loyalties and Party Defection', Comparative Political Studies, 42(6): 793-815.

Tavits, M. (2010), 'Effect of Local Ties on Electoral Success and Parliamentary Behaviour: the Case of Estonia', Party Politics, 16(2): 215-35.

Thijssen, P. (2013), 'Are Parties Stimulating Candidate-Centred Voting? The Case of the Belgian District Council Elections 2000-2006', Acta Politica, 48(2): 144-66.

Valdini, M.E. (2012), 'A Detterent to Diversity: The Conditional Effect of Electoral Rules on the Nomination of Women Candidates', Electoral Studies, 31(4): 740-49.

Van Aelst, P., Maddens, B., Noppe, J. and Fiers, S. (2008), 'Politicians in the News: Media or Party Logic? Media Attention and Electoral Success in the Belgian Election Campaign of 2003', European Journal of Communication, 23(2): 193-210.

van Holsteyn, J.J. and Andeweg, R.B. (2010), 'Demoted Leaders and Exiled Candidates: Disentangling Party and Person in the Voter's Mind', Electoral Studies, 29(4): 628-35.

Vanlangenakker, I., Maddens, B., and Put, G.J. (2013), 'Career Patterns in Multilevel States: An Analysis of the Belgian Regions', Regional Studies, 47(3): 356-67.

Verleden, F. (2009), 'Splitting the Difference: the Radical Approach of the Belgian Parties' in W. Swenden and B. Maddens (eds.), Territorial Party Politics in Western Europe (Basingstoke: Palgrave MacMillan): 145-66.

Wauters, B. and Weekers, K. (2008), 'Het Gebruik van de Voorkeurstem bij de Federale Parlementsverkiezingen van 10 Juni 2007', Res Publica: Tijdschrift voor Politologie, 50(2): 49-88.

Wauters, B., Weekers, K. and Pilet, J.B. (2004), 'Het Gebruik van de Voorkeurstem bij de Regionale en Europese Parlementsverkiezingen van 13 Juni 2004', Res Publica: Tijdschrift voor Politologie, 46(2-3): 377-412. 
Wauters, B., Weekers, K. and Maddens, B. (2010), 'Explaining the Number of Preferential Votes for Women in an Open-List PR System: an Investigation of the 2003 Federal Elections in Flanders (Belgium)', Acta Politica, 45(4): 468-90.

Table 1

Beta coefficients and standard errors of three random intercept fixed slope models with $\log (\%$ preferential votes) as dependent variable

\begin{tabular}{|c|c|c|c|c|}
\hline & \multicolumn{2}{|c|}{ Model 1} & \multicolumn{2}{|c|}{ Model 2} \\
\hline & $B$ & $S E$ & $B$ & $S E$ \\
\hline Intercept & $-0.185^{* * *}$ & $(0.039)$ & $-0.180 * * *$ & $(0.039)$ \\
\hline \multicolumn{5}{|l|}{ Candidate-level mechanical effects } \\
\hline \multicolumn{5}{|l|}{ List position (after $5^{\text {th }}$ position= ref.) } \\
\hline First & $2.761 * * *$ & $(0.053)$ & $2.712 * * *$ & $(0.053)$ \\
\hline Second & $0.654 * * *$ & $(0.061)$ & $0.590 * * *$ & $(0.061)$ \\
\hline Third & $0.388 * * *$ & $(0.048)$ & $0.379 * * *$ & $(0.048)$ \\
\hline Fourth & $0.246 * * *$ & $(0.046)$ & $0.243 * * *$ & $(0.046)$ \\
\hline Fifth & $0.151 * * *$ & $(0.046)$ & $0.146 * * *$ & $(0.046)$ \\
\hline Last but one & 0.004 & $(0.046)$ & -0.003 & $(0.045)$ \\
\hline Last & $0.286^{* * *}$ & $(0.048)$ & $0.247 * * *$ & $(0.048)$ \\
\hline Successor & $-0.133 * * *$ & $(0.019)$ & $-0.134 * * *$ & $(0.019)$ \\
\hline First successor & $0.193 * * *$ & $(0.050)$ & $0.196 * * *$ & $(0.049)$ \\
\hline Second successor & -0.045 & $(0.048)$ & -0.046 & $(0.047)$ \\
\hline \multicolumn{5}{|l|}{ List-level mechanical effects } \\
\hline$\%$ of list in constituency & $0.369 * * *$ & $(0.022)$ & $0.365 * * *$ & $(0.022)$ \\
\hline Candidate list for federal elections & & & 0.068 & $(0.047)$ \\
\hline \multicolumn{5}{|l|}{ Candidate characteristics } \\
\hline Gender & $-0.037 *$ & $(0.017)$ & $-0.035 *$ & $(0.017)$ \\
\hline First female candidate & -0.107 & $(0.061)$ & -0.062 & $(0.060)$ \\
\hline Age & $-0.018^{*}$ & $(0.009)$ & $-0.019 *$ & $(0.009)$ \\
\hline \multicolumn{5}{|l|}{ Profession (Employees =ref.) } \\
\hline Without job & 0.032 & $(0.029)$ & 0.030 & $(0.029)$ \\
\hline Self-employed & 0.021 & $(0.021)$ & 0.027 & $(0.021)$ \\
\hline Worker & 0.032 & $(0.047)$ & 0.037 & $(0.047)$ \\
\hline Civil servant & $-0.062 *$ & $(0.025)$ & $-0.055 *$ & $(0.025)$ \\
\hline Party professional & -0.018 & $(0.033)$ & -0.020 & $(0.033)$ \\
\hline Individual campaign spending & $0.105^{* * *}$ & $(0.020)$ & $0.110 * * *$ & $(0.020)$ \\
\hline Squared campaign expenses & -0.003 & $(0.003)$ & -0.003 & $(0.003)$ \\
\hline Former minister & $1.149 * * *$ & $(0.052)$ & $1.172 * * *$ & $(0.052)$ \\
\hline Former MP & $0.289 * * *$ & $(0.026)$ & $0.300 * * *$ & $(0.026)$ \\
\hline \multicolumn{5}{|l|}{ Local office (no office $=$ ref.) } \\
\hline Mayor & $0.205^{* * *}$ & $(0.040)$ & $0.271 * * *$ & $(0.062)$ \\
\hline Alderman & 0.005 & $(0.028)$ & -0.027 & $(0.042)$ \\
\hline Local councillor & 0.005 & $(0.019)$ & 0.019 & $(0.028)$ \\
\hline Relative municipality size & $0.024 * *$ & $(0.009)$ & 0.009 & $(0.014)$ \\
\hline \multicolumn{5}{|l|}{ Interaction effects } \\
\hline Mayor $*$ relative municipality size & & & $0.564 * * *$ & $(0.029)$ \\
\hline Alderman $*$ relative municipality size & & & $0.064 *$ & $(0.029)$ \\
\hline Local councillor $*$ relative municipality size & & & $0.038 *$ & $(0.018)$ \\
\hline Mayor $*$ list for federal elections & & & $0.183 *$ & $(0.075)$ \\
\hline Alderman $*$ list for federal elections & & & 0.061 & $(0.055)$ \\
\hline Local councillor * list for federal elections & & & -0.026 & $(0.038)$ \\
\hline List for federal elections $*$ rel. municipality size & & & -0.018 & $(0.017)$ \\
\hline
\end{tabular}




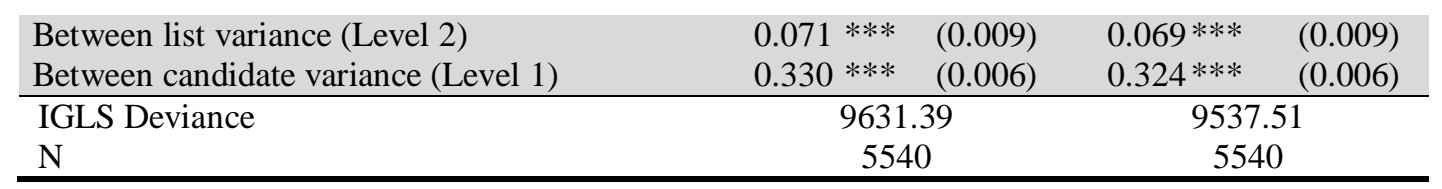

$* \mathrm{p}<0.05 ; * * \mathrm{p}<0.01 ; * * * \mathrm{p}<0.001$

\section{NOTES}

${ }^{1}$ Of course, this argument does not hold in political systems with high numbers of parachutists, hopping from one electoral district to another in between elections. Parachuting is not typical in the Belgian case (Pedersen et al. 2007). De Winter (1997) states that most Belgian MPs have strong local ties and have lived in their constituency most of their life.

${ }^{2}$ The following parties were included in the analysis : 2003 : CD\&V, VLD, SP.A-Spirit, N-VA, Vlaams Blok, Agalev; 2004 : CD\&V-N-VA, VLD, SP.A-Spirit, Vlaams Blok, Groen!; 2007 : CD\&V-N-VA, VLD, SP.ASpirit, Vlaams Belang, Groen!, LDD; 2009 : CD\&V, VLD, SP.A, Vlaams Belang, N-VA, Groen!, LDD, SLP; 2010 : CD\&V, VLD, SP.A, Vlaams Belang, N-VA, Groen!, LDD.

${ }^{3}$ Strictly speaking, the units of analysis are candidatures and not individual candidates, as politicians obviously stand in various consecutive elections.

${ }^{4}$ In the constituency of Brussel-Halle-Vilvoorde, where voters have a choice between Flemish and Francophone lists, the percentage of preferential votes was calculated on the basis of the total number of valid votes for the Flemish lists.

${ }^{5}$ We applied a natural log transformation. We also checked for outliers on the basis of the externally studentised residuals.

${ }^{6}$ The best example is Steve Stevaert, a Flemish socialist and former pub owner, who realized an exceptional individual result in the federal elections of 2003, making him a strong outlier in the dataset of election candidates. Stevaert's success was explained by his typical style of keeping things understandable and his strong local accent. Political opponents often labeled him as a populist. It would be virtually impossible, and also not desirable to include the candidate traits explaining Stevaert's success in our analysis.

${ }^{7}$ These are: age, municipality size, personal campaign investment, percentage of list in the constituency and the dependent variable.

${ }^{8}$ While the same argument could be made with regard to ethnic minority candidates, our data do not allow to do the same exercise for ethnic voters: only 3.5 of all candidates were labeled ethnic on the basis of a name recognition method similar to one used in Thijssen (2013). This implies that a candidate list contains on average only one ethnic candidate. We included this binary ethnic minority variable in the analysis, but found no significant effect (the variable was omitted from the reported analyses). In addition, given that there are so few ethnic minority candidates, it does not make sense to control additionally for the effect of being first ethnic candidate.

${ }^{9}$ Successor candidates form a separate and additional list of election candidates from each party in every constituency. In the event that an elected representative would not take up his/her seat, resigns or leaves his/her seat vacant due to death or illness, there would be no need for by-elections. the seat will be assigned to one of the successor candidates, again based on the interplay of rank order and the number of preferential votes.

${ }^{10} \mathrm{We}$ also ran the model with age as categorical variable to check for any curvilinear effects. None of the age categories had a significant effect on the dependent variable. 